\title{
Comparison Between Artificial Neural Networks and Response Surface Methodology to Predict the Bending Moment Capacity of Heat-treated Wood Dowel Joints
}

\author{
Sergiu Răcășan, Bogdan Bedelean,* Sergiu Georgescu, and Anca Maria Varodi \\ The bending moment capacity of heat-treated wood dowel joints loaded in \\ compression or tension was predicted via two artificial neural network \\ (ANN) models. Additionally, a comparative study between similar models \\ that were developed through response surface methodology (RSM) was \\ performed. The joints were made of heat-treated ash (Fraxinus excelsior). \\ The values of the ultimate failure load and the moment arms were \\ recorded for each run via a universal testing machine. To develop the ANN \\ models, the experimental data were randomly divided into three subsets, \\ which were needed for the training, testing, and validation phases. The \\ RSM models were obtained from the literature. The performances of the \\ models were analyzed in terms of the correlation coefficient, coefficient of \\ determination, root mean square error, mean square error, and mean \\ absolute prediction error. A sensitivity analysis was also performed to \\ observe potential changes in the results due to the uncertainty in the input \\ variables. The ANN model better predicted the bending moment capacity \\ of heat-treated wood dowel joints loaded in compression than the RSM \\ model. In contrast, the RSM model predicted the bending moment \\ capacity of joints loaded in tension more accurately than the ANN model.
}

Keywords: Artificial neural network; Response surface methodology; Modeling; Wood joints; Mechanical properties; Heat-treated wood

Contact information: Transilvania University of Brasov, Faculty of Wood Engineering, Universității Str. 1, 500036 Brasov, Romania; *Corresponding author: bedelean@unitbv.ro

\section{INTRODUCTION}

Joints are the most important component of structures designed to assure the strength of products (chairs, tables, doors, etc.). Therefore, product performance can be affected when structures are not well designed or are subjected to certain climatic conditions (Mollahassani et al. 2020). The dowel joint (Fig. 1) is the most common constructive solution in the furniture industry because it can be obtained fast and easily from a technological perspective and has a low manufacturing cost (Negreanu 2003; Abdolzadeh et al. 2015). In addition, dowel joints only require drilling operations to form a joint with high initial strength (Eckelman 2003).

The theoretical calculus of wood joint strength is a difficult task that depends on various factors, such as wood species, dowel length and diameter, depth of dowel embedment, adhesive type and consumption, and tightness of fit (Eckelman 2003; Kuzman et al. 2015; Diler et al. 2017; Georgescu et. al. 2019). More information regarding the factors that affect the strength of dowel joints has been reported (Eckelman 2003; Smardzewski 2015). Moreover, theoretical calculus requires a lot of simplifying assumptions that are not always realistic (Curtu et al. 1988; Smardzewski 2015; Bardak et al. 2017). Therefore, the use of mathematical models based on experimental data can 
represent a fast and reliable tool to predict the mechanical strength and optimal configuration of wood joints for a given scenario.

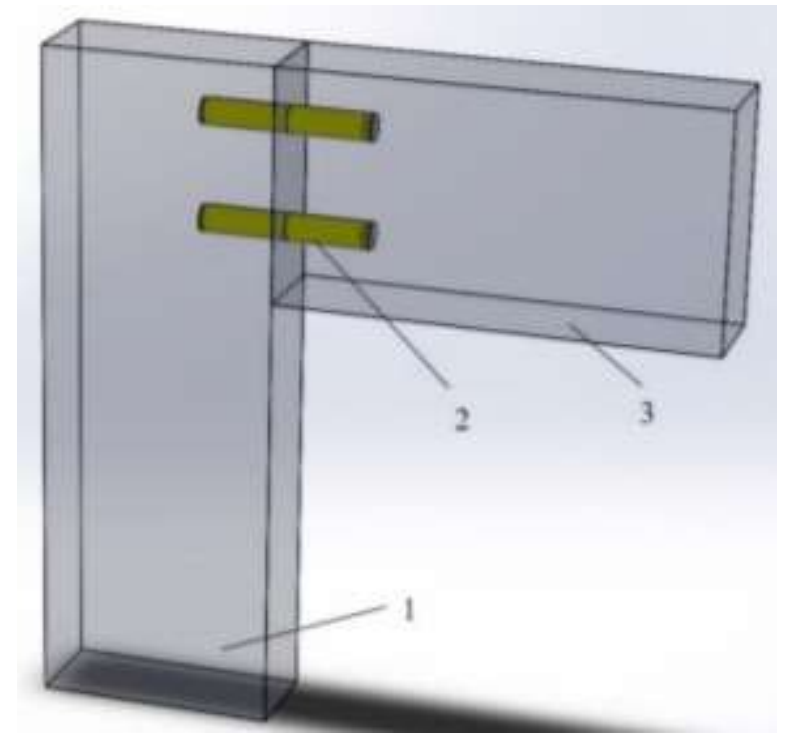

Fig. 1. The aspect of the analyzed dowel joint ( 1 is the leg, 2 is the wood dowel, and 3 is the rail)

The artificial neural networks (ANN) modeling technique, which is based on the behavior of the human brain, has been applied in wood engineering to predict various outputs, such as thermal conductivity, mechanical properties, swelling and shrinkage, reliability of the phytosanitary treatment of wood, equilibrium moisture content, and wood structure (Avramidis and Iliadis 2005; Watanabe et al. 2013; Tiryaki et al. 2016; Bedelean 2018; Ozsahin and Murat 2018). Modeling with ANN involves gathering the experimental data, transforming and dividing data for the training and testing sets, and performing the training, testing, and validation phase of the network. In summary, the main architecture of the ANN consists of three layers, which are the input layer, the hidden layer, and the output layer (Fig. 2). The input layer contains the independent variables, while the dependent variables are presented in the output layer. The relation between the independent and the dependent variables is determined via a hidden layer during the training phase. The number of neurons in the hidden layers (and/or the number of hidden layers) is often found through a trial-and-error approach. The background information about the artificial neural networks, such as the task of a neuron, determination of the number of neurons in each layer, and identification of the number of hidden layers and selecting a training algorithm, was found in the literature (Tiryaki and Aydin 2014).

However, modeling with response surface methodology (RSM) requires the development and execution of an experimental design. Typically, a central composite design is employed. The obtained data is statistically analyzed to determine the factors that influence the analyzed responses and identify the best polynomial model. The selected model could be used to predict the analyzed process or optimize it, after being validated with the experimental data. Anderson and Whitcomb (2005) also reported details on RSM. The RSM was applied in the wood science field to analyze and optimize the wood dowel joints, wood drying conditions (in a drying kiln), processing parameters of medium-density fiberboards, sanding parameters, and the mechanical properties of bamboo plywood (Yu et al. 2015; Șova et al. 2016; Hazir et al. 2017; Kumar et al. 2017; Georgescu et al. 2019). 
The ANN and RSM modeling techniques have been joined to optimize the flexural properties of gypsum-bonded fiberboards (Nazerian et al. 2018) and to determine the optimum surface roughness and lower power consumption in abrasive machining processes of wood (Tiryaki et al. 2017).

\section{Present work}

This study envisaged the comparison of two modeling techniques (ANN and RSM), in order to predict the bending moment capacity of heat-treated wood joints, loaded in compression or tension. The inputs included the dowel length, the dowel diameter, and the adhesive consumption. This is the first known comparative study regarding the application of both ANN and RSM to predict the bending moment capacity of heat-treated wood dowel joints. Also, this study aims to address the lack of comparative studies in the wood science field regarding the application of ANN and RSM modeling techniques to predict various outputs.

\section{EXPERIMENTAL}

\section{Materials}

The wood joints (Fig. 1) were obtained from a heat-treated ash (Fraxinus excelsior) board with a moisture content of $5 \%$ and an average density of $618 \mathrm{~kg} / \mathrm{m}^{3}$. The material was supplied by a local company from Brașov, Romania. The multi-groove dowel pins used in this research were made of beech wood (Fagus sylvatica). Polyvinyl acetate adhesive (Kleiberit 303; Kleiberit, Weingarten, Germany) and 5\% Kleiberit Turbo Hardener (Weingarten, Germany) were mixed to obtain a D4 adhesive, which was used for the joint assembly. After being assembled, the joints were conditioned for over one month in the same area where the compressive and tensile tests were performed. Additional information about the preparation of the joints was reported by Georgescu et al. (2019).

\section{Methods}

The analyzed factors were the dowel length $\left(\mathrm{X}_{1}\right)$, the dowel diameter $\left(\mathrm{X}_{2}\right)$, and the adhesive consumption $\left(\mathrm{X}_{3}\right)$. The responses were the bending moment capacity of joints loaded in compression ( $\mathrm{Y}_{\mathrm{Mc}}$ ) or tension ( $\mathrm{Y}_{\mathrm{Mt}}$ ) (Table 1 and Fig.2).

According to reference literature, testing the joints can be done through computer simulation by using the Finite Element Method (Yildirim 2015; Smardzewski 2015; Kaygin et al. 2017) and/or by experimental methods (Derikvand and Eckelman 2015; Bardak et al. 2017). In this work, the bending moment capacity of joints was determined by means of experiments.

The joints were subjected to diagonal compressive and tensile tests (Fig. 3) until major separation between the parts of the joints was observed (Yerlikaya and Aktas 2012; Kasal et al. 2015). A Zwick Roell Z10 testing machine (Zwick GmbH\&Co. KG, Ulm, Germany) was used to determine the ultimate compressive and tensile failure load of each analyzed dowel joint. During testing, the load was applied at a constant speed of $3 \mathrm{~mm} / \mathrm{min}$ (Kuzman et al. 2015). The bending moment capacities of the joints loaded in compression (Eq. 1) or tension (Eq. 2) were calculated based on the equations found in reference literature (Derikvand and Eckelman 2015; Georgescu et al. 2019). More information about the applied experimental design was reported by Georgescu et al (2019). Equation 1 and Eq. 2 were calculated as follows, 


$$
\begin{aligned}
& M_{\mathrm{c}}=F \times L_{\mathrm{c}} \\
& M_{\mathrm{t}}=F / 2 \times L_{\mathrm{t}}
\end{aligned}
$$

where $M_{\mathrm{c}}$ is the bending moment of joints loaded in compression $(\mathrm{Nm}), M_{\mathrm{t}}$ is the bending moment of joints loaded in tension, $F$ is the ultimate failure load $(\mathrm{N}), L_{\mathrm{c}}$ is the compression moment arm $(42 \mathrm{~mm})$, and $L_{\mathrm{t}}$ is the tension moment arm $(92 \mathrm{~mm})$.

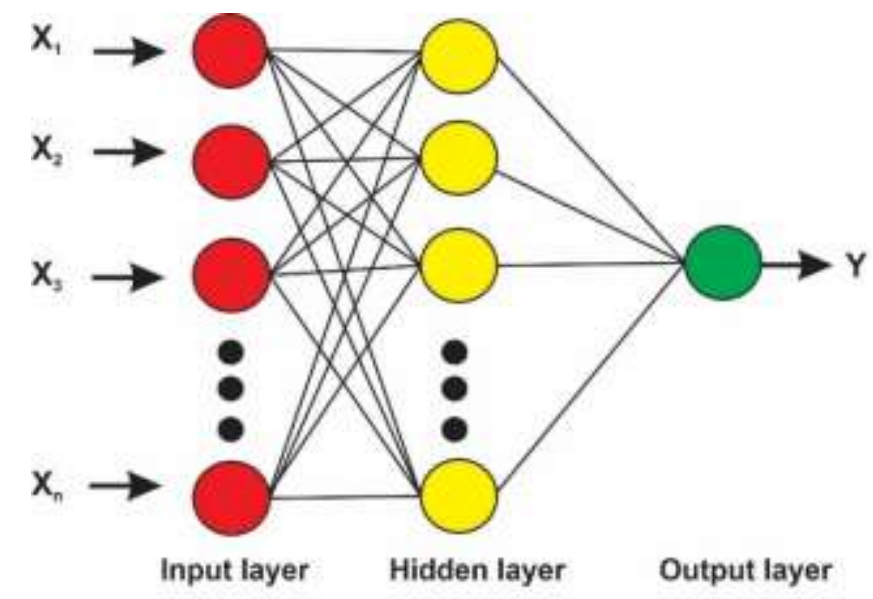

Fig. 2. Schematic aspect of an artificial neural network. $X_{1}, X_{2}, X_{3}$ and $X_{n}$ are independent variables (analyzed factors); $Y$ is the dependent variable (response).
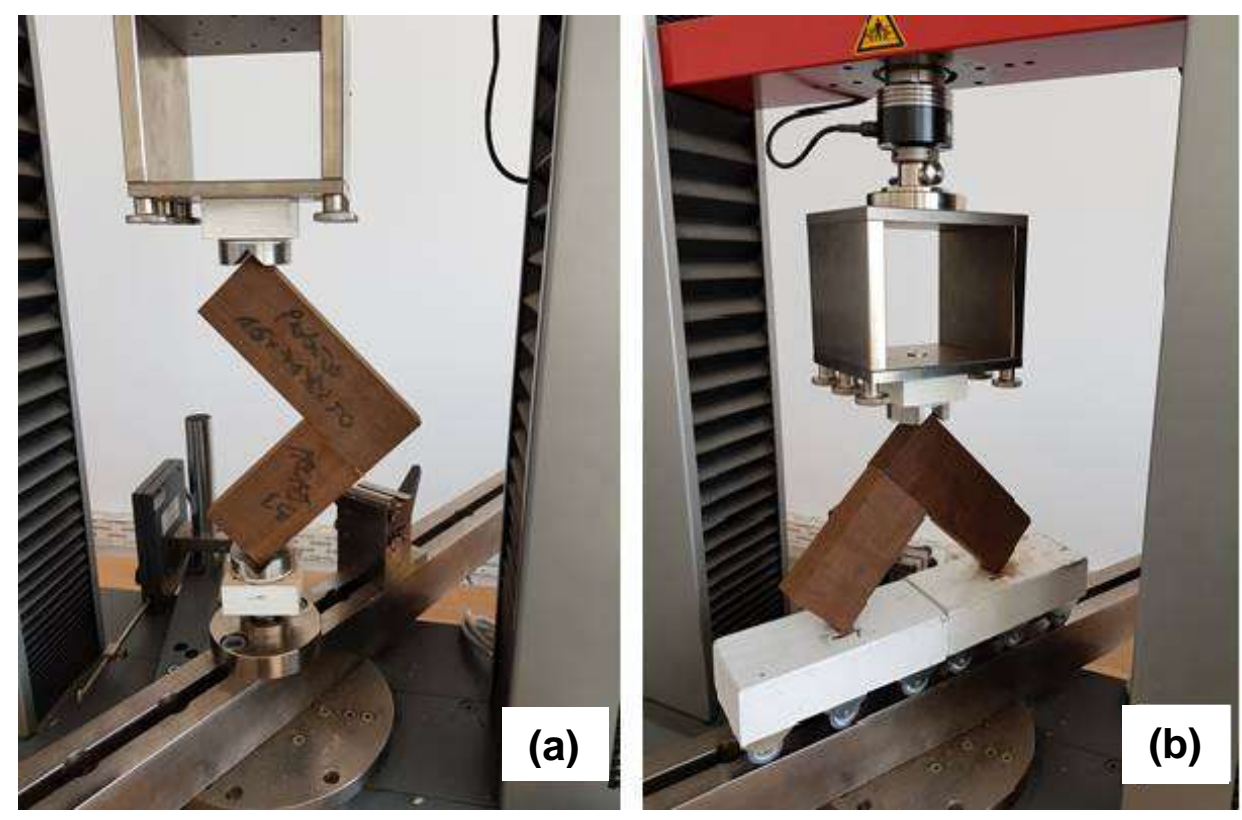

Fig. 3. The diagonal compression (a) and tensile (b) loading forms of the analyzed joints

The uncertainty of experimental values was obtained by means of the configuration 13 (Table 1). In this configuration, the independent variables were analyzed at the center level and repeated many times both during the compression and tension tests in order to obtain the experimental error (Georgescu et al. 2019). The values of the mean and the standard deviation of this experimental values are presented in Table 1. The uncertainty 
value (standard deviation of the repeated measurements) was equal to $\pm 16 \mathrm{Nm}$ in the case of compression test and equal to $\pm 31 \mathrm{Nm}$ in the case of tension test.

The ANN models were designed via NeuralWorks Predict Software (NeuralWare Inc., v.3.24.1, Carnegie, PA, USA). The experimental data were obtained from 246 joints for both compression and tension testing. To prepare the data prior to the training, testing and validation phases, the experimental values were randomized for each model (one model for compressive strength and the other for tensile strength). The data set that was used to develop each ANN model contained 174 cases and 72 cases for the validation phase, respectively. The software divided the data allocated for the model development so that the training and testing sets were similar from a descriptive statistics point of view. In addition, the data were converted into forms appropriate for neural networks and the cascade correlation algorithm was applied to create the multilayer structure of ANN. Watanabe et al. (2015) summarized the approach used by the NeuralWorks Predict software to develop an ANN model.

The RSM models, which predicted the bending moment capacity of heat-treated wood dowel joints that are loaded in compression (Eq. 3) or in tension (Eq. 4), were obtained from previously published work (Georgescu et al. 2019). These regression equations were used to determine the analyzed response based on the input factors (dowel length $\left(\mathrm{X}_{1}\right)$, dowel diameter $\left(\mathrm{X}_{2}\right)$, and adhesive consumption $\left(\mathrm{X}_{3}\right)$ ).

Table 1. Mean Experimental Values with Coefficient of Variation for the ANN Model

\begin{tabular}{|c|c|c|c|c|c|c|c|c|c|c|c|}
\hline \multirow{4}{*}{$\begin{array}{l}\text { Config. } \\
\text { No. }\end{array}$} & \multicolumn{3}{|c|}{ Input Factors } & \multirow{2}{*}{\multicolumn{8}{|c|}{$\begin{array}{c}\text { Output Factors } \\
\text { Bending Moment Capacity (Nm) }\end{array}$}} \\
\hline & \multirow{3}{*}{$\begin{array}{c}X_{1} \\
(\mathrm{~mm})\end{array}$} & \multirow{3}{*}{$\begin{array}{c}X_{2} \\
(\mathrm{~mm})\end{array}$} & \multirow{3}{*}{$\begin{array}{c}X_{3} \\
\left(g / m^{2}\right)\end{array}$} & & & & & & & & \\
\hline & & & & \multicolumn{4}{|c|}{ Compression ( $\left.Y_{\mathrm{Mc}}\right)$} & \multicolumn{4}{|c|}{ Tension $\left(Y_{M t}\right)$} \\
\hline & & & & M & $\mathrm{s}$ & $\begin{array}{l}\text { CV } \\
(\%)\end{array}$ & $\mathrm{n}$ & M & $s$ & $\begin{array}{l}\text { CV } \\
(\%)\end{array}$ & $\mathrm{n}$ \\
\hline 1 & 70 & 6 & 450 & 134 & 23 & 17 & 16 & 228 & 32 & 14 & 17 \\
\hline 2 & 30 & 10 & 250 & 68 & 8 & 12 & 17 & 129 & 15 & 12 & 17 \\
\hline 3 & 50 & 8 & 450 & 123 & 15 & 12 & 17 & 222 & 33 & 15 & 17 \\
\hline 4 & 70 & 10 & 250 & 143 & 13 & 9 & 17 & 241 & 31 & 13 & 18 \\
\hline 5 & 30 & 6 & 450 & 58 & 13 & 22 & 15 & 98 & 25 & 25 & 16 \\
\hline 6 & 30 & 10 & 450 & 102 & 16 & 16 & 16 & 197 & 22 & 11 & 16 \\
\hline 7 & 70 & 8 & 350 & 141 & 21 & 15 & 16 & 258 & 49 & 19 & 15 \\
\hline 8 & 30 & 8 & 350 & 71 & 12 & 17 & 16 & 137 & 22 & 16 & 17 \\
\hline 9 & 50 & 6 & 350 & 80 & 14 & 17 & 17 & 136 & 22 & 16 & 16 \\
\hline 10 & 50 & 8 & 250 & 92 & 18 & 20 & 17 & 160 & 21 & 13 & 17 \\
\hline 11 & 70 & 10 & 450 & 196 & 24 & 12 & 14 & 399 & 48 & 12 & 15 \\
\hline 12 & 70 & 6 & 250 & 95 & 12 & 13 & 17 & 154 & 31 & 20 & 17 \\
\hline 13 & 50 & 8 & 350 & 105 & 16 & 15 & 16 & 204 & 31 & 15 & 15 \\
\hline 14 & 30 & 6 & 250 & 43 & 9 & 22 & 18 & 85 & 14 & 17 & 17 \\
\hline 15 & 50 & 10 & 350 & 129 & 13 & 10 & 17 & 235 & 38 & 16 & 16 \\
\hline
\end{tabular}




$$
\begin{aligned}
& Y_{\mathrm{Mc}}=13.919-0.039 X_{1}-1.705 X_{2}-0.124 X_{3}+0.115 X_{1} X_{2}+0.002 X_{1} X_{3}+0.020 X_{2} X_{3} \\
& Y_{\mathrm{Mt}}=251.56-3.050 X_{1}-22.784 X_{2}-0.790 X_{3}+0.358 X_{1} X_{2}+0.009 X_{1} X_{3}+0.086 X_{2} X_{3}
\end{aligned}
$$

The performance of each model was analyzed via several indicators that are frequently used in the literature, such as correlation coefficient (R), coefficient of determination $\left(\mathrm{R}^{2}\right)$, root mean square error (RMSE), mean square error (MSE), and mean absolute prediction error (MAPE) (Tiryaki and Aydin 2014; Watanabe et al. 2015; Fu et al. 2017). Among these criteria, Tiryaki et al. (2017) claim that MAPE is the most important determinant of model performance. The correlation coefficient $(\mathrm{R})$ and the coefficient of determination $\left(\mathrm{R}^{2}\right)$ were calculated by means of Eqs. 5 and 6 . High $\mathrm{R}$ or $\mathrm{R}^{2}$ values indicate that the predicted data is close to the experimental data, the MAPE, MSE, and RMSE were calculated according to Eqs. 7, 8, and 9, respectively. Lower MAPE, MSE, and RMSE values reveal that the models perform well and have reasonable prediction accuracy.

Statistical parameters related to fitting are defined in Eqs. 5 through 9,

$$
\begin{aligned}
& \mathrm{R}=\frac{\sum_{i=1}^{N}\left(p_{i}-\bar{p}\right)\left(a_{i}-\bar{a}\right)}{\sqrt{\sum_{i=1}^{N}\left(p_{i}-\bar{p}\right)^{2}} \sqrt{\sum_{i=1}^{N}\left(a_{i}-\bar{a}\right)^{2}}} \\
& \mathrm{R}^{2}=1-\frac{\sum_{i=1}^{N}\left(a_{i}-p_{i}\right)^{2}}{\sum_{i=1}^{N}\left(a_{i}-\bar{a}\right)^{2}} \\
& \mathrm{MAPE}=\frac{1}{N}\left(\sum_{i=1}^{N}\left[\left|\frac{a_{i}-p_{i}}{a_{i}}\right|\right]\right) \times 100 \\
& \mathrm{MSE}=\frac{1}{N} \sum_{i=1}^{N}\left(a_{i}-p_{i}\right)^{2} \\
& \mathrm{RMSE}=\sqrt{\frac{1}{N} \sum_{i=1}^{N}\left(a_{i}-p_{i}\right)^{2}}
\end{aligned}
$$

where $N$ is the number of data points, $a_{\mathrm{i}}$ is the actual value of bending moment capacity $(\mathrm{Nm}), p_{\mathrm{i}}$ is predicted value of bending moment capacity $(\mathrm{Nm}), \bar{a}$ is mean of experimental values $(\mathrm{Nm})$, and $\bar{p}$ is the mean of predicted values $(\mathrm{Nm})$.

\section{RESULTS AND DISCUSSION}

The models were designed to predict the bending moment capacity of heat-treated wood dowel joints loaded in compression (22 Nm to $240 \mathrm{Nm}$ ) or tension (54 Nm to 447 $\mathrm{Nm}$ ) based on dowel length (30 mm to $70 \mathrm{~mm}$ ), dowel diameter (6 $\mathrm{mm}$ to $10 \mathrm{~mm}$ ), and adhesive consumption $\left(250 \mathrm{~g} / \mathrm{m}^{2}\right.$ to $\left.450 \mathrm{~g} / \mathrm{m}^{2}\right)$. The optimal structure of the ANN models contained three neurons in the input layer (dowel length, dowel diameter, and adhesive consumption) and one neuron in the output layer (bending moment capacity of joints loaded in compression or tension). In the hidden layer, there were two neurons for the ANN model developed to predict the compressive strength (Fig. 4a) and seven neurons for the model designed to predict the tensile strength (Fig. 4b). The architecture of the neural networks presented in Fig. 4 was different from that presented in Fig. 2 because the software in this work used the cascade-correlation learning algorithm. Therefore, the 
architecture was different from that of an ordinary multilayer feedforward network (Watanabe et al. 2015). The ANN models had high coefficients of correlation (R), which were greater than 0.9 during both the training and testing phases (Table 2).

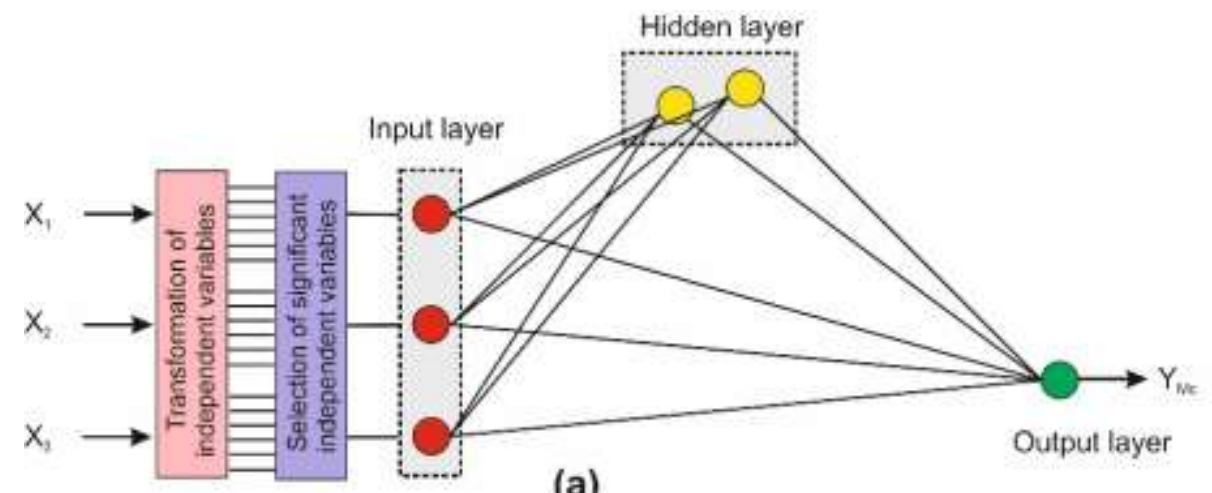

(a)

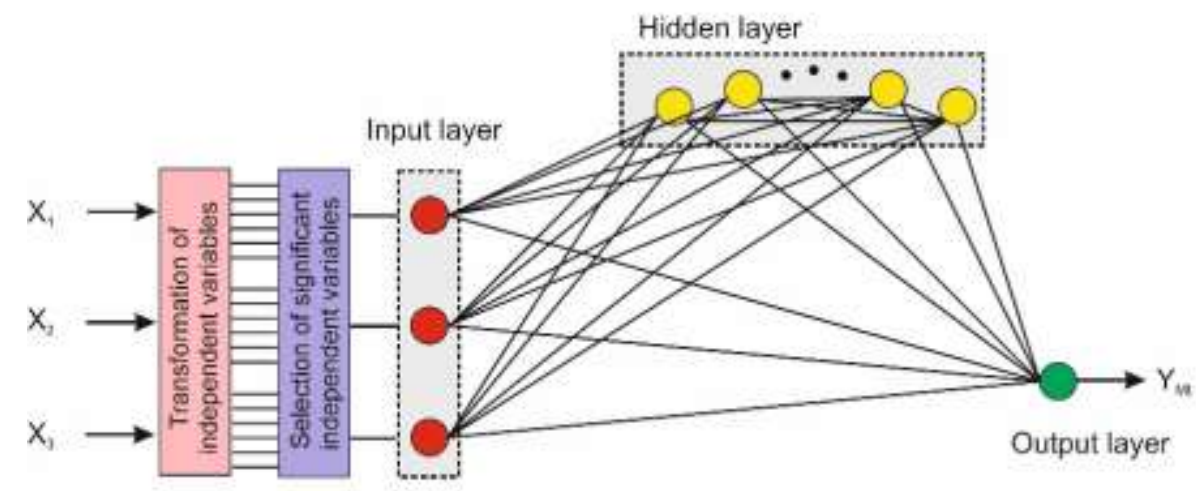

(b)

Fig. 4. Architecture of the artificial neural network model designed to predict the bending moment capacity of joints loaded in compression (a) or tension (b)

Table 2. Performance Criteria During the Training and Testing Phase

\begin{tabular}{|c|c|c|c|}
\hline \multirow{2}{*}{ Model } & \multicolumn{3}{|c|}{ Coefficient of Correlation (R) } \\
\cline { 2 - 4 } & Training & Testing & Validation \\
\hline Mc_ANN & 0.92 & 0.93 & 0.99 \\
\hline Mt_ANN & 0.92 & 0.95 & 0.98 \\
\hline
\end{tabular}

Comparing the predicted and experimental values (Figs. 5 and 6) showed that most of the predicted values were close to the experimental ones for both ANN models. However, based on the performance indicators (Table 3), the ANN model had a better fit with the experimental data than the RSM model for the bending moment capacity of joints loaded in compression. However, the RSM model predicted the bending moment capacity of joints loaded in tension more accurately than the ANN model. This finding can be explained by assuming that the relation between the independent variables and the bending moment capacity of joints loaded in compression is more nonlinear than in the case of tension strength, where the relation between independent and dependent variable could be considered close to be linear. Therefore, the ANN modeling technique performed better 
than RSM in the case of compressive model. However, both modeling techniques predicted the bending moment capacity of heat-treated wood dowel joints with high accuracy.

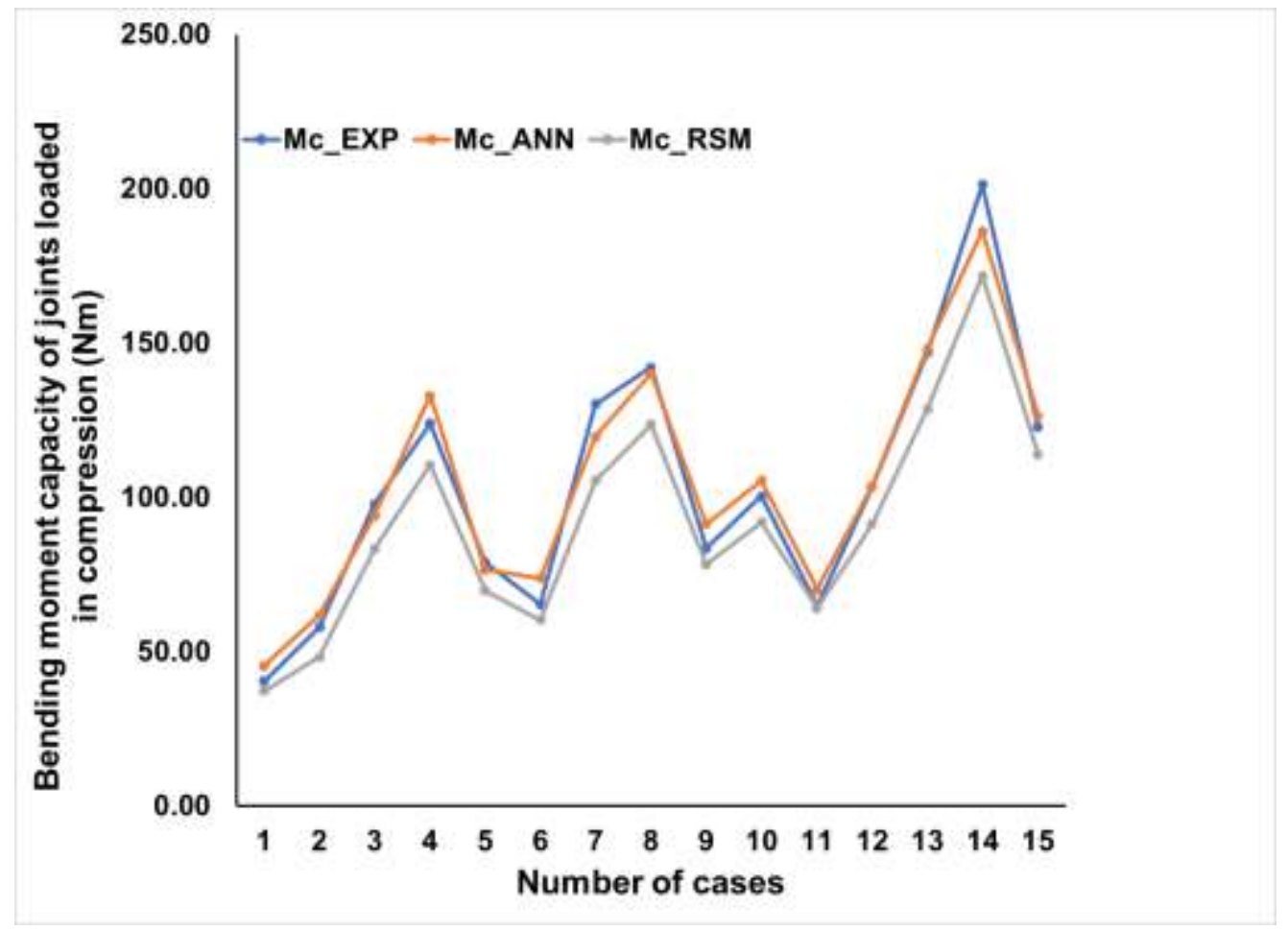

Fig. 5. Experimental and predicted values of compressive strength

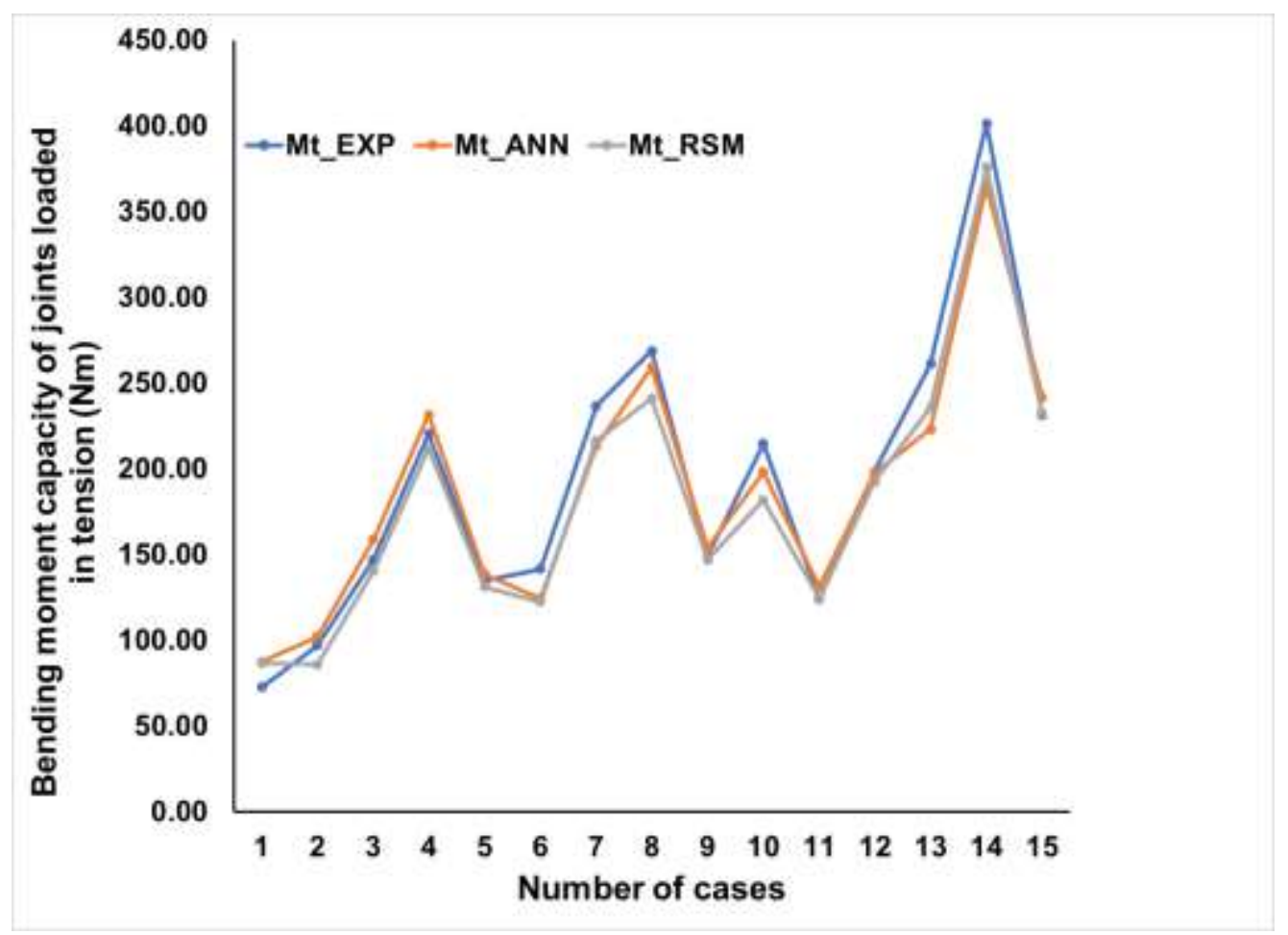

Fig. 6. Experimental and predicted values of tensile strength 
Table 3. Performance Obtained During the Validation Phase of the Models

\begin{tabular}{|c|c|c|c|c|c|}
\hline \multirow{2}{*}{ Model } & \multicolumn{5}{|c|}{ Performance Indicators } \\
\cline { 2 - 6 } & $\mathrm{R}$ & $\mathrm{R}^{2}$ & MAPE & MSE & RMSE \\
\hline Mc_ANN & 0.99 & 0.97 & 6.01 & 46.06 & 6.79 \\
\hline Mc_RSM & 0.99 & 0.98 & 10.85 & 205.56 & 14.34 \\
\hline Mt_ANN & 0.98 & 0.97 & 7.48 & 311.57 & 17.65 \\
\hline Mt_RSM & 0.99 & 0.98 & 7.36 & 294.31 & 17.16 \\
\hline
\end{tabular}

The applied sensitivity analysis revealed that the models developed to predict the bending moment capacity of joints loaded in compression or tension were sensitive to dowel length, dowel diameter, and adhesive consumption (Table 4). The sensitivity analysis was performed via the one-factor-at-a-time approach. The first step consisted of setting each independent variable to its central value of the analyzed range, according to the experimental plan presented in previous work (Georgescu et al. 2019). The second step consisted of varying one factor at a time while keeping all other parameters fixed. In the third step, the models were run to observe potential changes in the results due to the uncertainty of the input variables. In this work, an uncertainty of $\pm 10 \%$ was assumed for the inputs of the models. The sensitivity coefficient was calculated as the ratio of the change in the dependent variable to the corresponding change in the independent variable (Cronin and Gleeson 2006; Bedelean 2018).

Table 4. Results of Sensitivity Analysis for the ANN and RSM Models

\begin{tabular}{|c|c|c|c|c|c|c|c|c|c|c|}
\hline \multirow{3}{*}{$\begin{array}{l}\text { Independent } \\
\text { Variables }\end{array}$} & \multirow{3}{*}{$\begin{array}{c}\text { Central } \\
\text { Value of } \\
\text { Independen } \\
\text { t Variables }\end{array}$} & \multirow{3}{*}{$\begin{array}{l}\text { Change in } \\
\text { the } \\
\text { Independen } \\
\text { t Variables } \\
(\%)\end{array}$} & \multicolumn{4}{|c|}{$\begin{array}{c}\text { Change in the } \\
\text { Dependent Variables } \\
(\%)\end{array}$} & \multicolumn{4}{|c|}{ Sensitivity Coefficients } \\
\hline & & & \multicolumn{2}{|c|}{ ANN } & \multicolumn{2}{|c|}{ RSM } & \multicolumn{2}{|c|}{ ANN } & \multicolumn{2}{|c|}{ RSM } \\
\hline & & & Mc & $\mathrm{Mt}$ & Mc & $\mathrm{Mt}$ & $\mathrm{Mc}$ & Mt & Mc & $\mathrm{Mt}$ \\
\hline $\begin{array}{c}\text { Dowel } \\
\text { Length }\left(X_{1}\right)\end{array}$ & 50 & \pm 10 & 8.1 & $\begin{array}{c}10 . \\
0\end{array}$ & $\begin{array}{l}8 . \\
5\end{array}$ & 8.1 & $\begin{array}{c}0.8 \\
1\end{array}$ & 1.0 & $\begin{array}{c}0.8 \\
5\end{array}$ & $\begin{array}{c}0.8 \\
1\end{array}$ \\
\hline $\begin{array}{l}\text { Dowel } \\
\text { Diameter } \\
\left(\mathrm{X}_{2}\right)\end{array}$ & 8 & \pm 10 & $\begin{array}{c}10 . \\
5\end{array}$ & $\begin{array}{c}9.9 \\
5\end{array}$ & $\begin{array}{l}9 . \\
6\end{array}$ & $\begin{array}{c}11 . \\
0\end{array}$ & $\begin{array}{c}1.0 \\
5\end{array}$ & $\begin{array}{c}0.9 \\
9\end{array}$ & $\begin{array}{c}0.9 \\
6\end{array}$ & $\begin{array}{c}1.1 \\
0\end{array}$ \\
\hline $\begin{array}{c}\text { Adhesive } \\
\text { Consumptio } \\
\mathrm{n}\left(\mathrm{X}_{3}\right)\end{array}$ & 350 & \pm 10 & 4.7 & $\begin{array}{c}6.1 \\
3\end{array}$ & $\begin{array}{c}5 . \\
1\end{array}$ & 6.7 & $\begin{array}{c}0.4 \\
7\end{array}$ & $\begin{array}{c}0.6 \\
1\end{array}$ & $\begin{array}{c}0.5 \\
1\end{array}$ & $\begin{array}{c}0.6 \\
7\end{array}$ \\
\hline
\end{tabular}

The sensitivity analysis revealed that the ANN and RSM models developed to predict the bending moment capacity of joints loaded in compression were more sensitive to dowel diameter and less sensitive to dowel length and adhesive consumption. However, the ANN and RSM models developed to predict the bending moment capacity of joints loaded in tension were different, as the ANN model was more sensitive to the dowel length than the RSM model, which was more sensitive to dowel diameter.

\section{CONCLUSIONS}

1. The analyzed models predicted reliably and quickly the bending moment capacity of heat-treated wood dowel joints loaded in compression or tension without the need to perform experimental studies. 
2. The artificial neural network (ANN) model predicted the bending moment capacity of heat-treated wood dowel joints loaded in compression better than the response surface methodology (RSM) model.

3. The RSM model predicted the bending moment capacity of heat-treated wood dowel joints loaded in tension better than the ANN model.

4. The ANN model developed to predict the bending moment capacity of heat-treated dowel joints loaded in compression and the RSM model used to predict the same in tension were sensitive to uncertainty regarding the dowel diameter, dowel length, and adhesive consumption.

5. The ANN model designed to predict the bending moment capacity of heat-treated dowel joints loaded in tension was sensitive to dowel length, dowel diameter, and adhesive consumption.

\section{ACKNOWLEDGMENTS}

The authors are grateful for the support of the Transilvania University of Brasov in Romania (Grant No. 8019/14.07.2017).

\section{REFERENCES CITED}

Abdolzadeh, H., Ebrahimi, G., Layeghi, M., and Ghassemieh, M. (2015). “Analytical and experimental studies on stress capacity with modified wood members under combined stresses," Maderas. Ciencia y Tecnología 17(2), 263-276. DOI: 10.4067/S0718-221X2015005000025

Anderson, M. J., and Whitcomb, P. J. (2005). RSM Simplified: Optimizing Processes Using Response Surface Methods for Design of Experiments, CRC Press, Boca Raton, FL, USA.

Avramidis, S., and Iliadis, L. (2005). "Predicting wood thermal conductivity using artificial neural networks," Wood and Fiber Science 37(4), 682-690.

Bardak, T., Tankut, A. N., Tankut, N., Aydemir, D., and Sozen, E. (2017). “The bending and tension strength of furniture joints bonded with polyvinyl acetate nanocomposites," Maderas. Ciencia y Tecnología 19(1), 51-62. DOI: 10.4067/S0718221X2017005000005

Bedelean, B. (2018). "Application of artificial neural networks and Monte Carlo method for predicting the reliability of RF phytosanitary treatment of wood," European Journal of Wood and Wood Products 76(4), 1113-1120. DOI: 10.1007/s00107-0181312-1

Curtu, I., Nastase, V., Mihai, D., Mihailescu, T., and Stoian, O. (1988). Imbinări în Lemn. Structură, Tehnologie și Fiabilitate [Joints in Wood: Structure, Technology and Reliability], Technical Publishing House, Bucharest, Romania.

Cronin, K., and Gleeson, J. P. (2006). "Monte Carlo simulation," in: Handbook of Food and Bioprocess Modeling Technique, S. S. Sablani, A. K. Datta, M. S. Rahman, and A. S. Mujumdar (eds.), CRC Press, Boca Raton, FL, USA, pp. 502-530. 
Derikvand, M., and Eckelman, C. A. (2015). "Bending moment capacity of 1-shaped mitered frame joints constructed of MDF and particleboard," BioResources 10(3), 5677-5690. DOI: 10.15376/biores.10.3.5677-5690

Diler, H., Acar, M., Balıkçı, E., Demirci, S., and Erdil, Y. Z. (2017). "Withdrawal force capacity of T-type furniture joints constructed from various heat-treated wood species," BioResources 12(4), 7466-7478. DOI: 10.15376/biores.12.4.7466-7478

Eckelman, C. A. (2003). Textbook of Product Engineering and Strength Design of Furniture, Purdue University Press, West Lafayette, IN, USA.

Fu, Z., Avramidis, S., Zhao, J., and Cai, Y. (2017). "Artificial neural network modeling for predicting elastic strain of white birch disks during drying," European Journal of Wood and Wood Products 75, 949-955. DOI: 10.1007/s00107-017-1183-X

Georgescu, S., Varodi, A. M., Răcășan, S., and Bedelean, B. (2019). "Effect of the dowel length, dowel diameter, and adhesive consumption on bending moment capacity of heat-treated wood dowel joints," BioResources 14(3), 6619-6632. DOI: 10.15376/biores.14.3.6619-6632

Hazir, E., Koc, K. H., and Hiziroglu, S. (2017). "Optimization of sanding parameters using response surface methodology," Maderas. Ciencia y Tecnología 19(4), 407416. DOI: $10.4067 / S 0718-221 X 2017005000101$

Kasal, A., Eckelman, C. A., Haviarova, E., Erdil, Y. Z., and Yalcin, I. (2015). "Bending moment capacities of L-shaped mortise and tenon joints under compression and tension loadings," BioResources 10(4), 7009-7020. DOI: 10.15376/biores.10.4.70097020

Kaygin, B., Yorur, H., and Uysal, B. (2017). "Simulating strength behaviors of corner joints of wood constructions by using finite element method," Drvna Industrja 67(2), 133-140. DOI: $10.5552 /$ drind.2016.1503

Kumar, A., Sharma, K. V., Gupta, A., Tywoniak, J., and Hajek, P. (2017). “Optimization of processing parameters of medium density fiberboard using response surface methodology for multiwalled carbon nanotubes as a nanofiller," European Journal of Wood and Wood Products 75(2), 203-213. DOI: 10.1007/s00107-016-1106-2

Kuzman, M. K., Kutnar, A., Ayrilmis, N., and Kariz, M. (2015). "Effect of heat treatment on mechanical properties of selected wood joints," European Journal of Wood and Wood Products 73(5), 689-691. DOI: 10.1007/s00107-015-0931-z

Mollahassani, A., Hemmasi, A., Eslam, H. K., Lashgari, A., and Bazyar, B. (2020). "Dynamic and static comparison of beech wood dovetail, tongue and groove, halving, and dowel joints," BioResources 15(2), 3787-3798. DOI: 10.15376/biores.15.2.37873798

Nazerian, M., Kamyabb, M., Shamsianb, M., Dahmardehb, M., and Kooshaa, M. (2018). "Comparison of response surface methodology (RSM) and artificial neural networks (ANN) towards efficient optimization of flexural properties of gypsum-bonded fiberboards," CERNE 24(1), 35-47. DOI: 10.1590/01047760201824012484

Negreanu, C. (2003). Contributii la Studiul Imbinarilor cu Cepuri Cilindrice din Structura Mobilei din Lemn Masiv [Contributions to the Study of Dowel Joints that are Used in the Structure of Furniture Made of Solid Wood], Ph.D. Dissertation, Transilvania University of Brasov, Brasov, Romania.

Ozsahin, S., and Murat, M. (2018). "Prediction of equilibrium moisture content and specific gravity of heat-treated wood by artificial neural networks," European Journal of Wood and Wood Products 76(2), 563-572. DOI: 10.1007/s00107-0171219-2 
Smardzewski, J. (2015). Furniture Design, Springer International Publishing, Cham, Switzerland.

Sova, D., Bedelean, B., and Venetia, S. (2016). "Application of response surface methodology to optimization of wood drying conditions in a pilot-scale kiln," Baltic Forestry 22(2), 348-356.

Tiryaki, S., and Aydin, A. (2014). "An artificial neural network model for predicting compression strength of heat-treated woods and comparison with a multiple linear regression model," Construction and Building Materials 62, 102-108. DOI: 10.1016/j.conbuildmat.2014.03.041

Tiryaki, S., Bardak, S., Aydin, A., and Nemli, G. (2016). "Analysis of volumetric swelling and shrinkage of heat-treated woods: Experimental and artificial neural network modeling approach," Maderas. Ciencia y Tecnología 18(3), 477-492. DOI: 10.4067/S0718-221X2016005000043

Tiryaki, S., Ozsahin, S., and Aydin, A. (2017). "Employing artificial neural networks for minimizing surface roughness and power consumption in abrasive machining of wood," European Journal of Wood and Wood Products 75(3), 347-358. DOI: 10.1007/s00107-016-1050-1

Watanabe, K., Korai, H., Matsushita, Y., and Hayashi, T. (2015). "Predicting internal bond strength of particleboard under outdoor exposure based on climate data: Comparison of multiple linear regression and artificial neural network," Journal of Wood Science 61(2), 151-158. DOI: 10.1007/s10086-014-1446-7

Watanabe, K., Matsushita, Y., Kobayashi, I., and Kuroda, N. (2013). “Artificial neural network modeling for predicting final moisture content of individual Sugi (Cryptomeria japonica) samples during air-drying," Journal of Wood Science 59(2), 112-118. DOI: 10.1007/s10086-012-1314-2

Yldirim, N., Uysal, B., Ozcifci, A., Yorur, H., and Ozcan, S. (2015). "Finite element analysis (fatigue) of wooden furniture strength," in: Proceedings of XXVII Furniture Research Conference, Turkey, pp. 336-342.

Yerlikaya, N. Ç., and Aktaş, A. (2012). "Enhancement of load-carrying capacity of corner joints in case-type furniture," Materials \& Design 37, 393-401. DOI: 10.1016/j.matdes.2012.01.010

Yu, Y. S., Ni, C. Y., Yu, T., and Wan, H. (2015). "Optimization of mechanical properties of bamboo plywood," Wood and Fiber Science 47(1), 1-11

Article submitted: April 15, 2020; Peer review completed: May 16, 2020; Revised version received and accepted: May 30, 2020; Published: June 5, 2020.

DOI: 10.15376/biores.15.3.5764-5775 